\title{
Case management of malaria fever at community pharmacies in Pakistan: a threat to rational drug use
}

\author{
Madeeha MALIK, Mohamed A. HASSALI, Asrul A. SHAFIE, Azhar HUSSAIN, \\ Hisham ALJADHEY, Fahad SALEEM. \\ Received (first version): 11-Jan-2013 Accepted: 22-Mar-2013
}

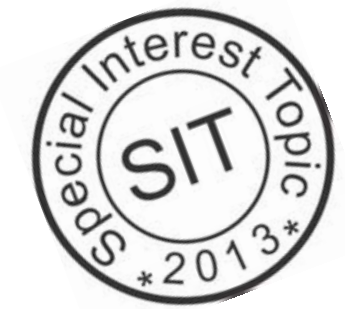

\begin{abstract}
*
Objective: To document the case management of uncomplicated malaria fever at community pharmacies located in the two major cities of Pakistan; Islamabad (national capital) and Rawalpindi (twin city).

Method: A comparative, cross-sectional study was designed to document the management of uncomplicated malaria fever at community pharmacies in twin cities of Pakistan through simulated patient visits. Visits were conducted in 238 randomly selected pharmacies to request advice for a simulated patient case of malaria. The pharmacy's management was scored on a checklist including history taking and provision of advice and information. Kruskal-Wallis test and Mann-Whitney $U$ test were used to compare management of uncomplicated malaria fever by different types of dispensers working at community pharmacies situated at different locations in the twin cities. Results: The simulated patients were handled by salesmen $(74.8 \%, \mathrm{n}=178)$, pharmacist $(5.4 \%, \mathrm{n}=13)$ and diploma holders $(19.8 \%, n=47)$. Medication was dispensed in $83.1 \%(n=198)$ of the visits, but only few of the treated cases were in accordance to standard treatment guidelines for malaria. However, in $14.8 \%(n=35)$ of the cases the simulated patients were directly referred to a physician. There was a significant difference observed in the process of
\end{abstract}

\footnotetext{
"Madeeha MALIK. B-Pharm (Hons), M-Phil (Pharmacy). Discipline of Social and Administrative Pharmacy, School of Pharmaceutical Sciences, Universiti Sains Malaysia. Penang, (Malaysia) \& Hamdard Institute of Pharmaceutical Sciences, Hamdard University. Islamabad, (Pakistan) Mohamed Azmi HASSALI. B-Pharm (Hons), MPharm (Clin. Pharm), PhD. Assistant Professor. Discipline of Social and Administrative Pharmacy, School of Pharmaceutical Sciences, Universiti Sains Malaysia. Penang (Malaysia).

Asrul Akmal SHAFIE. B-Pharm (Hons), Pg Dip Heath Econ, PhD. Senior Lecturer. Discipline of Social and Administrative Pharmacy, School of Pharmaceutical Sciences, Universiti Sains Malaysia. Penang (Malaysia). Azhar HUSSAIN, B-Pharm (Hons), M-Pharm (Clin.Pharm), PhD. Professor, Hamdard Institute of Pharmaceutical Sciences Hamdard University. Islamabad (Pakistan).

Hisham ALJADHEY, PharmD, PhD. Vice Dean for Academic Affairs, Director of Medication Safety Research Chair, College of Pharmacy, King Saud University. Riyadh (Saudi Arabia).

Fahad SALEEM, B-Pharm (Hons), M-Phil (Pharmacy). Discipline of Social and Administrative Pharmacy, School of Pharmaceutical Sciences, Universiti Sains Malaysia. Penang (Malaysia).
}

history taking performed by different dispensers (e.g. pharmacist, pharmacy assistant, pharmacy diploma holders and salesman) while no significant differences in the provision of advice by these dispensers was observed. Pharmacists were seen more frequently involved in the process of history taking if available at the community pharmacies. On the other hand, no significant differences were observed in the case management (history taking and provision of advice) for the treatment of malaria fever among community pharmacies situated at different locations (e.g. near hospital/super market/small market) in the twin cities.

Conclusion: The results of the study revealed that the overall process of disease management of uncomplicated malaria fever at community pharmacies was not in accordance with the national standard treatment guidelines for malaria. Patients were being treated by untrained personnel's at community pharmacies without any understanding of referral. However, pharmacists were more frequently involved in history taking, though their availability was low at community pharmacies.

Keywords: Community Pharmacy Services; Directive Counseling; Malaria; Pharmacies; Professional Practice; Patient simulation; Pakistan

\section{MANEJO DE CASOS DE MALARIA EN FARMACIAS COMUNITARIAS DE PAKISTÁN: AMENAZA AL USO RACIONAL DE MEDICAMENTOS}

\section{RESUMEN}

Objetivo: Documentar el manejo de casos de malaria no complicada en farmacias comunitarias situadas en las dos principales ciudades de Pakistán: Islamabad (la capital) y Rawalpindi (ciudad gemela).

Método: Se diseñó un estudio comparativo transversal para documentar el manejo de la malaria no complicada en las farmacias comunitarias de las ciudades gemelas de Pakistán mediante visitas de pacientes simulados. Se realizaron visitas a 238 farmacias aleatoriamente seleccionadas para pedir consejo en un caso de un paciente simulado con malaria. El manejo de la farmacia se puntuó en un listado que incluía la recogida del historial y la provisión de asesoramiento e información. Se utilizaron los tests de Kruskal-Wallis y de Mann-Whitney U para comparar el manejo de los casos de malaria no complicada por los dispensadores trabajando en 
farmacias comunitarias gestionadas por diferentes proveedores y en diferentes localizaciones de las ciudades gemelas.

Resultados: Los pacientes simulados fueron atendidos por vendedores $(74,8 \%, \mathrm{n}=178)$, farmacéuticos $(5,4 \%, n=13)$, y diplomados $(19,8 \%$, $\mathrm{n}=47)$. Se dispensó medicación en el $83,1 \%$ $(n=198)$ de las visitas, pero pocos de los casos tratados estaban de acuerdo con las recomendaciones para el tratamiento de la malaria. Sin embargo, en el $14,8 \%$ de los casos $(n=53)$ los pacientes simulados fueron remitidos directamente al médico. Hubo diferencia significativa en el proceso de recogida del historial entre los diferentes dispensadores (p.e. farmacéuticos, auxiliares de farmacia, diplomados en farmacia, y vendedores), mientras que no hubo diferencias significativas en la provisión de asesoramiento entre los diferentes dispensadores. Los farmacéuticos, si estaban disponibles en la farmacia, estaban más involucrados en el proceso de recogida del historial. Por otro lado, no se apreciaron diferencias significativas en el manejo del caso (recogida del historial y provisión de asesoramiento) para el tratamiento de la malaria entre las farmacias comunitarias de diferentes localizaciones de las ciudades gemelas (p.e. cerca de un hospital/supermercado/mercadillo).

Conclusión: Los resultados del estudio revelaron que el proceso general de manejo de la malaria no complicada en farmacias comunitarias no estaba de acuerdo con las recomendaciones nacionales de tratamiento de malaria. Los pacientes fueron atendidos por personal de las farmacias sin entrenamiento en las farmacias sin ninguna idea de remisión al médico. Sin embargo, los farmacéuticos estaban más involucrados en la recogida del historial, aunque su disponibilidad en las farmacias comunitarias era baja.

Palabras clave: Servicios de farmacias comunitarias; Consejo Dirigido; Malaria; Farmacias; Ejercicio profesional; Simulación de Paciente; Pakistán

\section{INTRODUCTION}

Community pharmacies are usually the first choice for the purchase of traditional drugs for treating common ailments and are a renowned primary source of advice regarding illness and drug therapy for both rural and urban populations, especially the poor. ${ }^{1}$ The reasons for preference of these pharmacies include convenience, shorter waiting times, less frequent drug stock-outs, longer operating hours and usually no fee for seeking advice. ${ }^{2,3}$ A dispenser is theoretically believed to be a trained person for preparing and dispensing medicines, but in real practice, a dispenser can be any person; he could be a qualified person (pharmacists, physicians, nurses or basic health workers) or an unqualified and untrained person (salesman), who is working at the retail outlets. ${ }^{4}$ Such personnel can only work under the direct supervision of pharmacists in developed countries but in the case of developing countries they work alone and without any supervision. They might perform duties inappropriate to their level of training. ${ }^{5}$

Anti-malarial drugs rank high among the drugs administered by the community pharmacies in most of the developing countries but effective management of malaria is not guaranteed: and the dispensing practices are under question. ${ }^{1,6}$ The involvement of dispensers in malaria treatment is predominantly high in developing countries and understanding their practices and knowledge regarding malaria treatment can assist in formulating strategies to improve current dispensing practices. Several studies reported that majority of the dispensers practicing at community pharmacies in developing countries had poor knowledge and dispensing behavior in relation to treatment of malaria. Most of them were unable to identify the recommended first-line treatment for uncomplicated malaria according to the national standard treatment guidelines. They had poor knowledge and skills to manage malaria cases appropriately. They usually failed to provide accurate information to patients on the dosage, likely side/adverse effects as well as instructions on how to take the medicines. Referral and counseling practices in case of malaria were seen limited. ${ }^{7-13}$ Thus, interventions to integrate the dispensers in the health system by improving their prescription, referral and counseling practices have been emphasized. ${ }^{1,9,14}$

There are approximately 63,000 community pharmacies in Pakistan. ${ }^{15}$ These pharmacies are operated by the proprietary medicine vendors and registered pharmacist licenses. There are three different types of licenses issued to the community pharmacies in Pakistan: type A (license of premises issued to a qualified person having a degree of $B$ Pharm/Pharm-D i.e. pharmacist), type B (license of premises issued to a qualified person having a diploma in pharmacy i.e. pharmacy assistant) and type $\mathrm{C}$ (license of premises issued to a person having a certificate of course completion in drug dispensing i.e. diploma holder). ${ }^{16}$ These pharmacies often lack ample facilities, staffing and equipments. ${ }^{17}$ These pharmacies are operated by variety of dispensers such as qualified pharmacist (degree of B- pharm/pharm D), pharmacy assistant (diploma in pharmacy), diploma holder (certified course of drug dispensing), to medical doctors, nurses and to the salespersons (people having no dispensing-related education) and majority represent this group. ${ }^{18}$ These salespersons have nominal education of primary or secondary level which is seen as a commercial necessity and not as a legal requirement to be followed. Although, these salespersons working at the pharmacies are not trained, but still, are involved in making diagnoses and recommending therapy to the patients along with dispensing of medicines. ${ }^{19-21}$ Shortage of qualified personnel at community pharmacies who could be engaged for ensuring good pharmacy practices is a common concern in Pakistan. ${ }^{5}$ Thus as a result, the dispensers working at these community pharmacies have inappropriate knowledge regarding disease management and 
dispensing practices at these pharmacies are compromised. ${ }^{18,20,21}$

Malaria is the foremost health problem of the people in Pakistan, being one of the five primary causes of out-patient visits and mortality. ${ }^{22}$ Malaria morbidity and mortality can be reduced through early diagnosis and effective anti-malarial treatment. ${ }^{23}$ But self-medication with anti-malarial drugs bought from community pharmacies is a common practice for the early treatment of fever in most of the developing countries including Pakistan. ${ }^{24-30}$ After the eighteenth amendment in Pakistan, a bill for creation of a federal drug regulatory authority was passed due to which the provincial assemblies ultimately conceded to the notion of federal drug regulation, through a resolution under Article 144 of the Constitution in 2012. The process of establishment of drug regulatory authority has been initiated but not completed yet. ${ }^{31,32}$ There is no updated list available in Pakistan indicating status of drugs as over-the-counter (OTC) or prescriptiononly-medicines (POM), generally all types of drugs without any restriction: ranging from paracetamol and anti-malarials to antibiotic, psychotropic drugs and narcotics are sold at the pharmacies which are outside the scope of their license. ${ }^{16,33}$ The current Drug Policy 1997 and Drug Act 1976 has many exploitable covenants and other gaps which are hoped to be addressed by the new federal drug regulatory authority. ${ }^{31,32}$ Although, there is no clear policy regarding status of anti-malarial drugs as OTC or POM drugs in Pakistan, but the national case management policy clearly states about the treatment. According to the guidelines malaria cases are categorized as follows: Uncomplicated malaria, complicated/severe malaria and malaria treatment failure malaria. As uncomplicated malaria might be treated at community pharmacies so the diagnosis and treatment relevant to it will be taken into account. The case definition for uncomplicated malaria is when a patient presents with fever or history of fever within last 72 hours (continuous, intermittent or irregular) with absence of signs of other diseases. Such patient might be highly suspected with possible exposure to malaria transmission. Although, laboratory confirmation is necessary for diagnosis of malaria but in case of uncomplicated malaria, if both microscopy and rapid diagnostic tests are not available, diagnosis of uncomplicated malaria might be considered based on history of possible exposure to malaria and a history of fever in the previous 3 days with no other obvious causes of fever. Various unspecific signs and symptoms might also be present, such as nauseas, vomiting, headache, body aches, sweating, rigors and history of intermittent fever. The treatment for uncomplicated malaria includes chloroquine plus premaquine for the treatment of malaria caused by Plasmodium vivax while artesunate plus sulphadoxine/pyrimathamine for the treatment of malaria caused by Plasmodium. falciparum is recommended. ${ }^{34}$ Inappropriate dispensing practices and self-medication for uncomplicated malaria can proceed swiftly to severe disease and may result in resistance of antimalarial drugs in treatment of Plasmodium falciparium and Plasmodium vivax in these countries. ${ }^{1,27-29}$ These threats have led to increasing calls for interventions to improve treatment practices offered at these outlets. ${ }^{26,35}$ Although, community pharmacies are considered as a major source of drugs, little has been reported on actual scenario at these pharmacies, especially from the perspective of case management of common ailments. ${ }^{24}$ However, before implementing such interventions, information about the current practices as well as the dispensing pattern of anti-malarial drugs at these pharmacies in Pakistan, must be explored. This study aims to document and compare the case management and referral practices of uncomplicated malaria at community pharmacies in twin cities of Pakistan. The results of the study will assist in designing appropriate interventions that will help in improving the practice.

\section{METHODS}

The cross sectional survey was conducted between February and April 2012. Simulated patient visits were performed in order to collect information on case management of malaria in terms of history taking and provision of advice and information at community pharmacies. The study was approved by Malaria Control Program, Pakistan and Hamdard Institute of Pharmaceutical Sciences, Hamdard University. Beside this the concerned drug inspectors of the area were contacted and written approval was obtained to carry out the research. Local chapters of chemist and druggist associations were also approached and informed regarding the research.

\section{Sampling of pharmacies and respondents}

The study population was all community pharmacy outlets selling allopathic medicines, or homeopathic or herbal medicines if sold alongside allopathic medicines. Any shop meeting this definition constituted the sampling unit; the sampling element included the dispenser working at these pharmacies. Simple random sampling technique was used to draw the sample of pharmacies from the list of community pharmacies obtained from respective district health offices by using lottery method. The total population of community pharmacies in Islamabad and Rawalpindi were 169 and 170 respectively. Sample size of community pharmacies in Islamabad $(n=118)$ and in Rawalpindi $(n=120)$ was calculated by using the formula at $95 \%$ confidence interval. ${ }^{36}$ Visits to request treatment advice for a patient were made to a total of 238 pharmacies.

\section{Data collection tool}

The data collection tool was adopted from the World Health Organization manual "How to investigate drug use in health facilities" and modified according to the objectives of the study. ${ }^{37}$ Focus group discussions were carried out with malariologists and clinicians working at Malaria Control Program, specialists, physicians, doctors and pharmacists from academia to discuss the content of the tool. Face and content validity were built through a panel of malariologists, clinicians, pharmacy research experts, community pharmacists, statisticians and 
by pilot testing. Cronbach alpha, applied to assess the reliability and internal consistency of the data, was $0.68 .^{38}$

The observation form included 24 items covering: demographic characteristics of the pharmacies, history of the illness, history of medication use, general medical history, outcome of the visit (medication dispensed or referral to physician) and advice regarding the dose, frequency, duration, use and side effects of any medication dispensed.

Case management was assessed with 2 subscales. These sub scales were designed according to the national case management guidelines for uncomplicated malaria which explains the minimum standards of history taking and provision of advice taken into account while managing uncomplicated malaria. The first sub scale scored the pharmacy outlet's compliance with 5 items about history taking: patient's age, patient's weight, history of illness, history of medication use and other medical history. According to the guidelines the dispenser must develop a friendly environment by greeting and then start recording the patient's particulars including age, weight, history of illness (fever or history of fever within last 72 hours (continuous, intermittent or irregular). Various unspecific signs and symptoms may be also present, such as nauseas, vomiting, headache, body aches, sweating), history of medication use (currently used medicine) and other medical history (absence of signs of other diseases causing fever). While the second checklist scored the outlet's compliance with 5 items concerning appropriate action taken provision of information about the medication dispensed in terms of: dose, frequency of doses, duration of use and side-effects/precautions in use. Although the appropriate action is referral of the patient to the physician. But as uncomplicated malaria might be treated at community pharmacies, so in case of treatment at community pharmacies two actions were considered most appropriate in this study i.e. suggesting an anti-pyretic and referring to the physician and other is the appropriate treatment for uncomplicated malaria caused by $P$. vivax (chloroquine plus primaquine along with an anti-pyretic). The prevalence of $P$. vivax is relatively more in the two selected cities for the present study, as being located in the province, Punjab while cases of $P$. falciparum are more frequently seen in Sindh, KPK and Baluchistan. ${ }^{39}$ Due to this reason the standard treatment for $P$. vivax was considered as the appropriate standard therapy for evaluating the practice in the current study. The correct provision of advice was assessed by comparing to the standard regimen for dose, frequency, duration (chloroquine tablets for three days (4 tab stat day $1+4$ tab stat day $2+2$ tab stat day 3), primaquine tab (One tablet a day for 14 days) and side effects. The principle limiting adverse effects which should be communicated to the patient was considered to be the unpleasant taste and pruritus in case of choroquine while abdominal pain might be caused by premaquine if administered on an empty stomach. Other less common side effects include headache, gastrointestinal disturbances, such as nausea, vomiting and diarrhea.

The minimum requirement for history taking and provision of medication information was elaborated and transformed into measurable indicators. In both scales the scores were computed on the basis of 1=yes and 2=no, so the total score was between 510 with lower scores indicating better case management. Similar scoring system has been used in several other studies. 18,33,40,41 The form included additional information such as provider type, location of pharmacy, type of license, outcome of the visit (medication dispensed or referral to physician) and suggestions of remedy.

\section{Data collection}

Data was collected by trained data collectors after obtaining permission from the relevant district health officer and drug inspectors. The data collectors were local students in their final year of the Doctor of Pharmacy program. Two teams, one in each city comprising of five data collectors in each team were trained by the group of experts including the principal investigator who visited all 238 pharmacies along with the data collectors to reduce the potential limitations associated with relying on data collector recall. Both male and female data collectors were involved. WHO manual was used for the training of data collectors as simulated patients. ${ }^{42}$ The data collector presented him/ herself to pharmacy with complaints of fever, chills and abdominal cramping and stated that he/she wanted to buy drugs for medical treatment. Other than the standard complaint/symptoms no information was presented unless asked for by the dispenser. One visit was made to each selected pharmacy and the data collectors recorded the management of the encounter at the end of each visit using the structured observation form. They documented any questions that the pharmacy attendant/dispenser asked before making a recommendation, including any discussion on the need for medication and on alternative therapy/ advice, any explanation given about the product recommended; and any advice, such as how to treat the condition or when to see a doctor. Any product that was finally recommended was purchased in the quantities suggested. The principal investigator ensured that the observation forms of each pharmacy were compiled and labelled with the name and location of the pharmacy. The therapy proposed by dispensers was compared for right drug, right dose, frequency, duration, strength and use with the national standard treatment guidelines for malaria.

\section{Data analysis}

The data were sorted for any missing data and coded and entered in SPSS, version 16. Kruskal Wallis and Mann Whitney $U$ tests were performed to compare case management of malaria by community pharmacies with reference to independent variables such city, location of pharmacy (in supermarket, in small market or near hospital) and type of dispenser (salesperson, diploma holder or pharmacist). 


\begin{tabular}{|c|c|c|c|c|}
\hline \multirow[t]{2}{*}{ Indicators } & $\begin{array}{c}\text { Islamabad } \\
n=118\end{array}$ & $\begin{array}{c}\text { Rawalpindi } \\
n=120\end{array}$ & $\begin{array}{c}\text { Composite } \\
n=238\end{array}$ & \multirow[t]{2}{*}{ p-value } \\
\hline & $\mathrm{N}(\%)$ & $\mathrm{N}(\%)$ & $\mathrm{N} \%$ & \\
\hline Age of patient was asked & $2(1.7)$ & $27(22.5)$ & $29(12.1)$ & ${ }^{\star} 0.001$ \\
\hline Weight of patient was asked & $2(1.7)$ & $3(2.5)$ & $5(0.02)$ & 0.508 \\
\hline History of illness was asked & $84(70.6)$ & $82(68.4)$ & $166(69.7)$ & 0.637 \\
\hline History of medication was asked & $34(28.6)$ & $51(42.5)$ & $85(35.7)$ & ${ }^{\star} 0.031$ \\
\hline Medical History was asked & $0(0)$ & $15(12.5)$ & $15(6.3)$ & ${ }^{\star} 0.001$ \\
\hline Patient referred directly to physician & $19(16.1)$ & $16(13.3)$ & $35(14.8)$ & 0.065 \\
\hline Remedy was suggested \& dispensed & $96(81.3)$ & $102(85.0)$ & $198(83.1)$ & 0.433 \\
\hline Patient not referred and no remedy suggested & $3(2.6)$ & $2(1.7)$ & $5(2.1)$ & 0.681 \\
\hline
\end{tabular}

\section{RESULTS}

A total of 238 simulated patient visits for management of malaria fever were carried out. Of the 238 community pharmacies visited, 49.5\% $(n=118)$ were situated in Islamabad and $50.5 \%$ $(n=120)$ in Rawalpindi. Of which $75.6 \%(n=180)$ were located in urban areas while remaining $24.4 \%$ $(n=58)$ were located in rural areas. These pharmacies were present in diverse settings including near hospitals $(15.6 \%, \mathrm{n}=37)$, in main super markets $(68 \%, \mathrm{n}=162)$ and remaining $16.4 \%$ $(n=39)$ were established in small markets. In $21.8 \%$ $(n=52)$ of the cases pharmacies had type A license, $61 \%(n=145)$ had type B and $10.5 \%(n=25)$ type C. While $6.7 \%(n=16)$ did not display their license. The patients were handled by salesmen $(74.8 \%, n=178)$, pharmacist $(5.4 \%, \mathrm{n}=13)$ and diploma holders $(19.8 \%, \mathrm{n}=47)$.

The scores on the history taking observation checklist showed that patient's age was enquired about in $12.1 \%(n=29)$ and history of current illness in $69.7 \%(n=166)$ of the visits. On the other hand the pharmacy personnel asked about history of medication use in $35.7 \%(n=85)$, medical history in $6.3 \%(n=15)$ and weight of the patient in only $0.02 \%$ $(n=5)$ of the cases. Medication was dispensed in $83.1 \%(n=198)$ of the visits, while in $14.8 \%(n=35)$ of the cases the customer was referred directly to a physician; while in $2.1 \%(n=5)$ of the cases the patient was neither referred nor a remedy was suggested. Chi Square test was used to find out association among different indicators of history taking performed at community pharmacies in the twin cities. There were significant differences seen among different indicators of history taking performed at community pharmacies in the twin cities. A detail description is given (Table 1).

Out of 238 visits, simulated patients were treated in $83.1 \%(n=198)$ of the cases. Of the total treated cases, anti-malarials were given in $28.3 \%(n=56)$, antibiotics in $34.4 \% \quad(n=68)$ while NSAIDs were given in $37.3 \%(n=74)$ of the cases. On the other hand, a total of 217 drugs were dispensed in the treated cases, of which $34.6 \%(n=75)$ were antimalarials, $31.3 \%(n=68)$ antibiotics and $34.1 \%$ $(\mathrm{n}=74)$ were NSAIDs (Table 2$)$.

Different types of treatment regimens were used for the management of malaria fever at community pharmacies located in the twin cities. The treatment therapy constituted of monotheray as well as combination therapy. Monotherapy with single antimalarial drug was given in $12.6 \% \quad(n=25)$, combination of single anti-malarial drug with an antibiotic and NSAID in $6 \% \quad(n=12)$ while a combination of two anti-malarial drugs along with an NSAID was administered in $9.6 \%(n=19)$ of the total treated cases. A detail description of different treatment regimens is given (Table 3 ).

The scores on the medication information checklist showed that appropriate drugs were given in 15.6\% $(n=31)$ of the cases for the treatment of malaria fever at community pharmacies situated in the twin cities. While correct dose of medicine for the treatment of malaria was communicated to the customer in $14.6 \%(n=29)$ of cases, frequency of treatment in $10.1 \%(n=20)$, duration of regimen in $11.1 \%(n=22)$ and possible side effects/ cautions of drugs were communicated in $1.5 \%(n=3)$ of the cases (Table 4).

Mann-Whitney $U$ test was used to compare the case management of malaria fever at community pharmacies situated in the different cities. There was a significant difference in the process of history taking while no significant difference in the provision of medication information for the treatment of malaria fever at community pharmacies located in the twin cities was observed. The process of history taking was being performed more frequently at community pharmacies situated in Rawalpindi as compared to those located in Islamabad (Table 5).

Kruskal-Wallis test was used to compare the case management of malaria fever performed by different types of dispensers (e.g. pharmacist, pharmacy diploma holders and salesman) working at

\begin{tabular}{|c|c|c|c|c|c|c|}
\hline \multirow[b]{2}{*}{ Type of Medicines Dispensed } & \multicolumn{2}{|c|}{ Islamabad } & \multicolumn{2}{|c|}{ Rawalpindi } & \multicolumn{2}{|c|}{ Composite } \\
\hline & $\begin{array}{c}\text { Cases } \\
\text { treated } \\
\mathrm{N}(\%)\end{array}$ & $\begin{array}{c}\text { Drugs } \\
\text { dispensed } \\
\mathrm{N}(\%)\end{array}$ & $\begin{array}{c}\text { Cases } \\
\text { treated } \\
\mathrm{N}(\%)\end{array}$ & $\begin{array}{c}\text { Drugs } \\
\text { dispensed } \\
\mathrm{N}(\%)\end{array}$ & $\begin{array}{c}\text { Cases } \\
\text { treated } \\
\mathrm{N}(\%)\end{array}$ & $\begin{array}{c}\text { Drugs } \\
\text { dispensed } \\
\mathrm{N}(\%)\end{array}$ \\
\hline Anti-malarials & 34 (35.4) & $44(41.6)$ & $22(21.6)$ & $31(28.0)$ & $56(28.3)$ & $75(34.6)$ \\
\hline NSAIDs & $34(35.4)$ & $34(32.0)$ & $40(39.2)$ & $40(36.0)$ & $74(37.3)$ & $74(34.1)$ \\
\hline Antibiotics & $28(29.2)$ & $28(26.4)$ & 40 (39.2) & $40(36.0)$ & $68(34.4)$ & 68 (31.3) \\
\hline Total & $\begin{array}{c}96 \\
(100.0)\end{array}$ & $\begin{array}{c}106 \\
(100.0)\end{array}$ & $\begin{array}{c}102 \\
(100.0)\end{array}$ & $\begin{array}{c}111 \\
(100.0)\end{array}$ & $\begin{array}{c}198 \\
(100.0)\end{array}$ & $\begin{array}{c}217 \\
(100.0)\end{array}$ \\
\hline
\end{tabular}




\begin{tabular}{|c|c|c|c|}
\hline \multirow[b]{2}{*}{ Different treatment regimens used for malaria fever } & \multicolumn{3}{|c|}{ Treated Cases } \\
\hline & $\begin{array}{c}\text { Islamabad } \\
n=96 \\
F(\%)\end{array}$ & $\begin{array}{c}\text { Rawalpindi } \\
n=102 \\
F(\%) \\
\end{array}$ & $\begin{array}{c}\text { Composite } \\
n=198 \\
F(\%) \\
\end{array}$ \\
\hline Single anti-malarial drug only & $15(15.6)$ & $10(9.8)$ & $25(12.6)$ \\
\hline Two anti-malarial drugs + one NSAID & $10(10.4)$ & $9(8.8)$ & $19(9.6)$ \\
\hline One anti-malarial + one antibiotic + one NSAID & $9(9.3)$ & $3(2.9)$ & $12(6.0)$ \\
\hline Single antibiotic only & $13(13.4)$ & $22(21.5)$ & $35(17.6)$ \\
\hline One antibiotic + one NSAID & $6(6.2)$ & $15(14.7)$ & $21(10.0)$ \\
\hline Single NSAID only & $9(9.3)$ & $13(12.7)$ & $22(11.1)$ \\
\hline
\end{tabular}

community pharmacies situated at different locations (e.g. near hospital/super market/small market) in the twin cities of Pakistan. There was a significant difference observed in the process of history taking performed by different dispensers (e.g. pharmacist, pharmacy assistant, pharmacy diploma holders and salesman) while no significant differences in the provision of advice by these dispensers was observed. Pharmacists were seen more frequently involved in the process of history taking if available at the community pharmacies. On the other hand, there were no significant differences seen in the case management (history taking and provision of advice) for the treatment of malaria fever among community pharmacies situated at different locations (e.g. near hospital/super market/small market) in the twin cities (Table 6).

\section{DISCUSSION}

This study documents the case management of dispensers for the treatment of malaria fever at community pharmacies in Pakistan. The results of the study revealed that the overall process of disease management of uncomplicated malaria fever at community pharmacies in Pakistan was not in accordance to the standard treatment guidelines. The findings of the study supports the assumption that the community pharmacies in Pakistan have converted into places of medical practice, carried out by untrained dispensers. These dispensers have been recognized to come in the business from diverse backgrounds without having adequate knowledge of illness and management and are likely to contribute to inappropriate dispensing practices. Similar findings of inappropriate dispensing of anti-malarial drugs due to inadequate knowledge of dispensers were reported in Nigeria. 1,6,26

The results of the study showed that history taking was a missing component at the community pharmacies, however, overall, pharmacists were more frequently involved in history taking, though their availability was low at community pharmacies. The low presence of qualified person can be related to the poor enforcement of laws and low or no demand by the community. Due to the ambiguity and poor implementation of law, the qualified persons rent their license to the owners of pharmacies thus not only indulging in illegal practice but also undermining their importance as health care professionals. Studies have reported inappropriate diagnosis and treatment by the unqualified and untrained pharmacy attendants and pharmacists appeared to perform better than the other staff. ${ }^{43,44}$ The overall process of history taking by dispensers before product recommendation was ignored at community pharmacies situated in different locations in the twin cities of Pakistan. Referral of malaria cases was not common. This might be due to poor understanding, lack of training and unavailability of the skilled personnel regarding management of malaria at community pharmacies. These results are similar to other studies conducted in various countries including Pakistan. 6,7,19,45

The results of the current study showed that malaria was being treated empirically on the basis of signs and symptoms with anti-malarials, antibiotics and NSAIDs without any laboratory confirmation. Only few of the treated cases were in accordance with the national standard treatment guidelines for malaria. This clearly reflects lack of knowledge regarding standard regimen, confusion of dispenser's in symptoms of malaria, lack of understanding of appropriate diagnosis and referral. This might be due to the fact that the dispensers are usually not involved in the preparation of standard treatment guidelines and do not receive any training on the treatment guidelines before they are implemented, changed or updated. Similar pattern

\begin{tabular}{|l|c|c|c|}
\hline Table 4 Provision of advice for the treatment of malaria fever at community pharmacies in the twin cities \\
\hline \multirow{2}{*}{ Information communicated } & $\begin{array}{c}\text { Islamabad } \\
\mathrm{n}=96\end{array}$ & $\begin{array}{c}\text { Rawalpindi } \\
\mathrm{n}=102\end{array}$ & $\begin{array}{c}\text { Composite } \\
\mathrm{n}=198\end{array}$ \\
\cline { 2 - 4 } & $\mathrm{N}(\%)$ & $\mathrm{N}(\%)$ & $\mathrm{N}(\%)$ \\
\hline Dose of drug & $33(34.3)$ & $22(21.5)$ & $55(27.7)$ \\
\hline Frequency of drug & $34(35.4)$ & $22(21.5)$ & $56(28.2)$ \\
\hline Duration of drug & $32(33.3)$ & $20(19.6)$ & $52(26.2)$ \\
\hline Use of drug & $22(22.9)$ & $12(11.7)$ & $34(17.1)$ \\
\hline Side effects/cautions & $3(3.1)$ & $6(5.8)$ & $9(4.5)$ \\
\hline \multicolumn{5}{|l|}{} \\
\hline Correct drug Sub Scale 2: Approve provision of advice & $31(15.6)$ \\
\hline Correct dose of drug & $16(16.6)$ & $15(14.7)$ & $29(14.6)$ \\
\hline Correct frequency of drug & $15(15.6)$ & $14(13.7)$ & $20(10.1)$ \\
\hline Correct duration of drug & $12(12.5)$ & $8(7.8)$ & $22(11.1)$ \\
\hline Correct side effects/cautions & $14(14.5)$ & $8(7.8)$ & $3(1.5)$ \\
\hline
\end{tabular}




\begin{tabular}{|c|c|c|c|c|c|c|c|c|}
\hline \multirow[b]{2}{*}{ Cities } & \multicolumn{4}{|c|}{ History taking } & \multicolumn{4}{|c|}{ Provision of advice } \\
\hline & $\begin{array}{c}\text { No of } \\
\text { pharmacies } \\
\text { visited }\end{array}$ & $\begin{array}{c}\text { Median } \\
\text { scale } \\
\text { score }\end{array}$ & $U$ & $p$-value & $\begin{array}{c}\text { No of } \\
\text { pharmacies } \\
\text { visited }\end{array}$ & $\begin{array}{c}\text { Median } \\
\text { scale score }\end{array}$ & $U$ & $p$-value \\
\hline Islamabad & 118 & 9 & \multirow{2}{*}{5.71} & \multirow{2}{*}{$0.008^{*}$} & 118 & 10 & \multirow{2}{*}{5.99} & \multirow{2}{*}{0.130} \\
\hline Rawalpindi & 120 & 8 & & & 120 & 10 & & \\
\hline
\end{tabular}

of poor case management of malaria and lack of involvement of dispensers in formulation and training on treatment guidelines have been reported by other studies. $6,7,26,39$

Counseling is an important determinant in ascertaining the method of medicine use by the patient. The information communicated should include advice on appropriate use, when to expect symptoms of relief, potential side effects, dose and frequency of the drug. ${ }^{2}$ The results of the present study showed that the overall process of advice and information given at community pharmacies in the twin cities was inadequate irrespective of the type of dispenser and location of the pharmacy. The provision of advice for treating the common symptoms of malaria was negligible or was not in accordance with standard therapy, highlighting a shortage of qualified and trained personnel at these pharmacies. Low quality of professional services from pharmacies with little or no verbal advice to the patients in treatment of malaria and no formal arrangement to facilitate referral were reported in various developing countries including Nigeria. ${ }^{1,28,47}$

The current regulations, with necessary changes, should be enforced to ensure the availability of qualified people at community pharmacies. Pharmacists shall be encouraged to come into the community pharmacy business with introduction of incentives by the government. Training programs for dispensers and specifying their minimum education to work as dispensers should be a regular feature of District Health Office and the attendance of dispensers can be ensured by linking it with the renewal of their pharmacy licenses. The program should also be embedded in the National Malaria Control Drug Policy of the country which aims at achieving rational use of medication and control of malaria through public private partnership. The limitation of resources in the feasibility and sustainability of implementation of such innovative program, as the initial cost of setting the program is usually high, can be minimized by including the annual running costs of the program within a typical district budget. Dispensers should be involved in the preparation, sensitization and training of guidelines on all the necessary drug updates to control antimalarial drug resistance and unnecessary financial burdens on the patients due to inappropriate information provided to the patients by the out-ofdate dispensers.

\section{Limitations of the study}

The study was conducted in the two cities of Pakistan and the results of the study may not be generalized to other parts of the country. The use of simulated clients is an effective methodology for assessing practices but use of external data collectors can create biasness in the response of the dispensers. Pharmacy staff may not have taken the client's requests seriously, being able to observe that they are not actually sick (since they weren't sick, but were actually testing the staff on their responses) and may not have treated them as accurately or as seriously as they would have a client with true symptoms.

\section{CONCLUSIONS}

The results of the study revealed that the overall process of disease management of uncomplicated malaria fever at community pharmacies was not in accordance with the national standard treatment guidelines for malaria. Patients were being treated by untrained personnel's at community pharmacies without any understanding of referral. The overall process of history taking and medication counseling at community pharmacies was limited. However, pharmacists were more frequently involved in history taking, though their availability was low at community pharmacies. Dispensers presently working at the community pharmacies should be trained on referral, history taking and importance of patient counselling to improve the current dispensing practices. The government should actively seek the participation of community pharmacies through advocacy, training and imparting a sense of ownership in the National Malaria Control program for the effective treatment and control of malaria in Pakistan.

\begin{tabular}{|c|c|c|c|c|c|c|c|c|}
\hline \multirow[t]{2}{*}{ Variables } & \multicolumn{4}{|c|}{ History taking } & \multicolumn{4}{|c|}{ Provision of advice } \\
\hline & $\begin{array}{c}\text { No of } \\
\text { pharmacies } \\
\text { visited }\end{array}$ & $\begin{array}{l}\text { Median } \\
\text { scale } \\
\text { score }\end{array}$ & $\mathrm{H}$ & $p$ - value & $\begin{array}{c}\text { No of } \\
\text { pharmacies } \\
\text { visited }\end{array}$ & $\begin{array}{l}\text { Median } \\
\text { scale } \\
\text { score }\end{array}$ & $\mathrm{H}$ & $\mathrm{p}$ - value \\
\hline $\begin{array}{r}\text { Location of pharmacy } \\
\text { Near hospital } \\
\text { In Supermarket } \\
\text { In Small market }\end{array}$ & $\begin{array}{c}37 \\
162 \\
39\end{array}$ & $\begin{array}{l}9 \\
9 \\
9\end{array}$ & 4.73 & 0.094 & $\begin{array}{c}37 \\
162 \\
39\end{array}$ & $\begin{array}{l}10 \\
10 \\
10\end{array}$ & 0.15 & 0.924 \\
\hline $\begin{array}{r}\text { Type of provider } \\
\text { Pharmacist } \\
\text { Diploma holder } \\
\text { Salesman }\end{array}$ & $\begin{array}{c}13 \\
47 \\
178\end{array}$ & $\begin{array}{l}8 \\
9 \\
9\end{array}$ & 10.22 & $0.006^{*}$ & $\begin{array}{c}13 \\
47 \\
178\end{array}$ & $\begin{array}{l}10 \\
10 \\
10\end{array}$ & 1.30 & 0.520 \\
\hline
\end{tabular}




\section{CONFLICT OF INTEREST}

None declared.

References

1. Okeke TA, Uzochukwu BS, Okafor HU. An in-depth study of patent medicine sellers' perspectives on malaria in a rural Nigerian community. Malar J. 2006;5:97.

2. Puspitasari HP, Aslani P, Krass I. A review of counseling practices on prescription medicines in community pharmacies. Res Social Adm Pharm. 2009;5(3):197-210. doi: 10.1016/j.sapharm.2008.08.006

3. Brugha R, Zwi A. Improving the quality of private sector delivery of public health services: challenges and strategies. Health Policy Plan. 1998;13(2):107-20.

4. Adome RO, Whyte SR, Hardon A, Popular pills: Community drug use in Uganda1996. Netherlands: Aksant Academic Publishers, 1996.

5. Azhar S, Hassali MA, Ibrahim MI, Ahmad M, Masood I, Shafie AA. The role of pharmacists in developing countries: the current scenario in Pakistan. Hum Resour Health. 2009;7:54. doi: 10.1186/1478-4491-7-54.

6. Erhun WO, Osagie A, Management of malaria by medicine retailers in a Nigerian urban community. J Health Popul Dev Ctries. 2004;8:1-6.

7. Tekobo AM, Tayo F. Knowledge and practice of drug retailers in malaria management in Lagos Nigeria: A preliminary survey. Nig Q J Hosp Med. 2004;14(1):84-7.

8. Marsh VM, Mutemi WM, Willetts A, Bayah K, Were S, Ross A, Marsh K. Improving malaria home treatment by training drug retailers in rural Kenya. Trop Med Int Health. 2004;9(4):451-60.

9. Rajakaruna RS, Weerasinghe $\mathrm{M}$, Alifrangis $\mathrm{M}$, Amerasinghe $\mathrm{PH}$, Konradsen $\mathrm{F}$. The role of private drug vendors as malaria treatment providers in selected malaria endemic areas of Sri Lanka. J Vector Borne Dis. 2006;43(2):58-65.

10. Tawfik Y, Nsungwa-Sabitii J, Greer G, Owor J, Kesande R, Prysor-Jones S. Negotiating improved case management of childhood illness with formal and informal private practitioners in Uganda. Trop Med Int Health. 2006;11(6):967-73.

11. Hetzel MW, Dillip A, Lengeler C, Obrist B, Msechu JJ, Makemba AM, Mshana C, Schulze A, Mshinda H. Malaria treatment in the retail sector: knowledge and practices of drug sellers in rural Tanzania. BMC Public Health. 2008;8:157. doi: 10.1186/1471-2458-8-157.

12. Rusk A, Smith N, Menya D, Obala A, Simiyu C, Khwa-Otsyula B, O'Meara W. Does anti-malarial drug knowledge predict anti-malarial dispensing practice in drug outlets? A survey of medicine retailers in western Kenya. Malar $\mathrm{J}$. 2012;11:263. doi: 10.1186/1475-2875-11-263.

13. Buabeng KO, Matowe LK, Smith F, Duwiejua M, Enlund H. Knowledge of medicine outlets' staff and their practices for prevention and management of malaria in Ghana. Pharm World Sci. 2010;32(4):424-31. doi: 10.1007/s11096-010-93976.

14. Marsh VM, Mutemi WM, Muturi J, Haaland A, Watkins WM, Otieno G, Marsh K. Changing home treatment of childhood fevers by training shop keepers in rural Kenya. Trop Med Int Health. 1999;4(5):383-9.

15. Babar Z. Medicalising Pakistan. 2007. Available from: http://www.chowk.com/articles/11520 (Accessed 2009 20th November)

16. Hussain A, Ibrahim MI, Baber ZU. Compliance with Legal Requirements by Community Pharmacies in Pakistan: a cross sectional survey. Int J Pharm Pract. 2012;20(3):183-90. doi: 10.1111/j.2042-7174.2011.00178.x

17. Hussain A, Ibrahim MI, Baber ZU. Compliance with legal requirements at community pharmacies:A cross sectional study from Pakistan. Int J Pharm Pract. 2012;20(3):183-90. doi: 10.1111/j.2042-7174.2011.00178.x.

18. Hussain A, Ibrahim MI. Qualification, knowledge and experience of dispensers working at community pharmacies in Pakistan. Pharm Pract. 2011; 9(2):93-100.

19. Hussain A, Ibrahim MI. Medication counselling and dispensing practices at community pharmacies: A comparative cross sectional study from Pakistan. Int J Clin Pharm. 2011;33(5):859-67. doi: 10.1007/s11096-011-9554-6.

20. Butt ZA, Gilani AH, Nanan D, Sheikh AL, White F. Quality of pharmacies in Pakistan: a cross-sectional survey. Int J Qual Health Care. 2005;17(4):307-13

21. Rabbani F, Cheema FH, Talati N, Siddiqui S, Syed S, Bashir S, Zuberi LZ, Shamim A, Mumtaz Q. Behind the counter:pharmacies and dispensing patterns of pharmacy attendants in Karachi. J Pak Med Assoc. 2001;51(4):149-53.

22. Malik M, Hassali MA, Shafie AA, Hussain A. Prescribing practices for the treatment of malaria among public and private facilities: A comparative cross sectional study from Pakistan. Health Med. 2012. 6(4):1147-54.

23. World Health Organization. World Malaria Report 2012. 2012; Available from: http://www.who.int/malaria/publications/world_malaria_report_2012/wmr2012_full_report.pdf (Accessed 2013 15th January)

24. Brieger WR, Osamor PE, Salami KK, Oladepo O, Otusanya SA. Interactions between patent medicine vendors and customers in urban and rural Nigeria. Health Policy Plan. 2004;19(3):177-82.

25. McCombie SC. Self-treatment for malaria: the evidence and methodological issues. Health Policy Plan. 2002;17(4):33344.

26. Goodman C, Brieger W, Unwin A, Mills A, Meek S, Greer G. Medicine sellers and malaria treatment in sub-Saharan Africa: what do they do and how can their practice be improved? Am J Trop Med Hyg. 2007;77(6 Suppl):203-18.

27. Goodman C, Kachur SP, Abdulla S, Bloland P, Mills A. Drug shop regulation and malaria treatment in Tanzania-why do shops break the rules, and does it matter? Health Policy Plan. 2007;22(6):393-403 
28. Greer G, Akinpelumi A, Madueke L, Plowman B, Fapohunda B, Tawfik Y, Holmes R, Owor J, Gilpin U, Clarence C, Bob Lenno B. Improving management of childhood malaria in Nigeria and Uganda by improving practices of patent medicine vendors. Arlington, Va: USAID, 2004.

29. Idowu OA, Mafiana CF, Luwoye IJ, Adehanloye O. Perceptions and home management practices of malaria in some rural communities in Abeokuta, Nigeria. Travel Med Infect Dis. 2008;6(4):210-4. doi: 10.1016/j.tmaid.2007.10.007.

30. Malik M, Hassali MA, Shafie AA, Hussain A, Aljadhey H. Availability of different strengths of anti-malarial preparations in Pakistan: Implication for patient safety. J Pharmacol Biomed Anal. 2012, 1:1

31. Nishtar, S. Drug Regulatory Authority: A Case for Hope? . 2012; Available from: http://www.huffingtonpost.co.uk/drsania-nishtar/drug-regulatory-authority_b_2270449.html (Accessed 201225 December)

32. Nishtar S. Devolving health-Part - II 2011; Available from: http://www.thenews.com.pk/Todays-News-9-65635Devolving-health-Part---Il (Accessed 2012 15th March)

33. Hussain A, Ibrahim MI. Medication counseling and dispensing practices at community pharmacies: a comparative cross sectional study from Pakistan. Int J Clin Pharm. 2011;33(5):859-67. doi: 10.1007/s11096-011-9554-6.

34. World Health Organization and Malaria Control Program Directorate, National treatment guidelines for malaria, 2005, Pakistan; Ministry of Health Pakistan: 2005.

35. Gomes M, Wayling S, Pang L. Pang, Interventions to improve the use of antimalarials in south-east Asia: an overview. Bull World Health Organ. 1998;76(Suppl 1):9-19.

36. Israel GD, Determining sample size. Available from http://edis.ifas.ufl.edu/pdffiles/PD/PD00600.pdf

37. INRUD, How to investigate drug use in health facilities, WHO, Editor 2002.

38. Field A, Discovering statistics using SPSS, T. Oaks, Editor, California: SAGE: 2009.

39. Malik M, Hussain A, Hassali MA, Shafie AA. Standard treatment guidelines for malaria: Challenges in its implementation in Islamabad (federal capital) and Rawalpindi (twin city), Pakistan. Saudi Pharm J. 2013;21(1):123-124.

40. Hussain A, Ibrahim MI, Malik M. Assessment of disease management of acute respiratory tract infection at community pharmacies through simulated visits in Pakistan. Latin Am J Pharm. 2012; 31(10):1435-40.

41. Hussain A, Ibrahim MI. Management of diarrhea cases by community pharmacies in 3 cities of Pakistan. East Mediterr Health J. 2012;18(6):635-40.

42. World Health Organization. How to investigate drug use in health facilities:Selected drug use indicators; Available from: http://apps.who.int/medicinedocs/pdf/s2289e/s2289e.pdf (Accessed 2002 20th April)

43. Rajeswari R, Balasubramanian R, Bose MS, Sekar L, Rahman F. Private pharmacies in tuberculosis control—a neglected link. Int J Tuberc Lung Dis. 2002;6(2):171-3.

44. Turner AN, Ellertson C, Thomas S, García S. Diagnosis and treatment of presumed STIs at Mexican pharmacies: survey results from a random sample of Mexico City pharmacy attendants. Sex Transm Infect. 2003;79(3):224-8.

45. Tumwikirize WA, Ekwaru PJ, Mohammed K, Ogwal-Okeng JW, Aupont O. Management of acute respiratory infections in drug shops and private pharmacies in Uganda a study of counter attendants' knowledge and reported behaviour. East Afr Med J. 2004;(Suppl):S33-40.

46. Minzi OM, Haule AF. Poor Knowledge On New Malaria Treatment Guidelines Among Drug Dispensers In Private Pharmacies In Tanzania: The Need For Involving The Private Sector In Policy Preparations And Implementation. East Afr J Public Health. 2008;5(2):117-21.

47. Smith LA, Jones C, Meek S, Webster J. Review: Provider practice and user behavior interventions to improve prompt and effective treatment of malaria: do we know what works? Am J Trop Med Hyg. 2009;80(3):326-35. 